\title{
Survival stamina as a function of social interaction
}

\author{
WILLIAM T. RIVERO \\ Louisiana State University, Baton Rouge, La. 70803
}

The present experiment was undertaken in an attempt to determine possible effects of social facilitation upon survival stamina of rats running on a motorized treadmill. Forty albino rats were used as Ss. A two-tailed t test indicated that paired rats ran significantly $(p<.05)$ longer than did single rats. The data implied that as a result of social facilitation, animal pairs exhibited greater survival stamina than did single animals.

Although many psychologists have studied the various social organizations which exist among animals, few, if any, have studied the effects of such interaction in avoidance situations (Allee, 1938; Altman, 1967; Alverdes, 1927; Young, 1961). The majority of experimentation concerning social organization has dealt with its facilitory effects upon learning, nutritional acquisition, and consumption (Allee, 1931; Gates \& Allee, 1933; Harlow, 1932). With the exception of studies done by Anderson (1939), Lepley (1937), and Winslow (1940), which dealt with social interaction in competitive situations, little has been done to discern the effects of social facilitation in any type of stressful situation.

The present experiment is an attempt to determine the possible effects of what Altman (1967, p. 455), Harlow (1932), and Yudin (1933, p. 171) refer to as "social facilitation" upon an avoidance situation. Altman defined social facilitation "as a phrase that refers to the observed phenomenon of the initiation or induction of the performance of an act as a result of its exhibition by others [1967, p. 455]."' The experimental hypothesis contends that paired groupings of rats will exhibit stronger survival stamina as measured by running time on a treadmill than will single animals in the same situation. If one is to assume that social facilitation exists in avoidance situations as well as competitive stress situations, such a hypothesis will be found to be consistent with the findings of Waters, Rethlingshafer, \& Ealdwell (1960).

\section{SUBJECTS}

The Ss consisted of 40 male albino rats, weighing between 235 and $375 \mathrm{~g}$. APPARATUS

The apparatus consisted of a stopwatch and a variable-speed motor-driven treadmill, $17 \times 28$ in., which was enclosed by an 8-in. wall with plastic top. A $4 \times 17$ in. shocking grid was located at the rear of the canvas belt.

\section{PROCEDURE}

Twenty Ss were assigned randomly to a single group (S1) and 20 Ss were assigned to a paired group (P1). The $20 \mathrm{Ss}$ in the $\mathrm{S} 1$ group were individually placed on the treadmill, which was running at $2 \mathrm{ft} / \mathrm{sec}$. Each $\mathrm{S}$ was run until complete exhaustion ensued. Ten consecutive seconds on the shocking grid was used as criterion for complete exhaustion. A similar procedure was used for Ss in the P1 group run in pairs. The first rat to reach criterion in the $\mathrm{P} 1$ group was immediately removed without stopping the treadmill. Using a stopwatch, E recorded the total length of time, to the nearest sixth of a minute, that each $S$ spent in the apparatus. All Ss were run at sea level at a temperature of $70^{\circ} \mathrm{F}$.

$$
\text { RESULTS }
$$

Table 1 exhibits the mean times of the $\mathrm{P} 1$ and $\mathrm{S} 1$ groups, indicating a consistent superiority of running endurance attained by the P1 groups. A two-tailed $t$ test indicated that $P 1$ Ss ran significantly $(p<.05)$ longer than did S1 Ss.

Table 1 Endurance Time

\begin{tabular}{|c|c|c|c|}
\hline \multicolumn{2}{|c|}{ S1 Group } & \multicolumn{2}{|c|}{ Pl Group } \\
\hline $\begin{array}{l}\text { Weight } \\
\text { (Grams) }\end{array}$ & Minutes & $\begin{array}{c}\text { Weight } \\
\text { (Grams) }\end{array}$ & Minutes \\
\hline 352 & 18 & 335 & $251 / 2$ \\
\hline 375 & $471 / 2$ & 375 & $471 / 2$ \\
\hline 370 & 22 & 320 & $201 / 3$ \\
\hline 320 & 27 & 320 & 34 \\
\hline 280 & 30 & 265 & 26 \\
\hline 340 & $321 / 2$ & 265 & 38 \\
\hline 340 & 24 & 320 & 37 \\
\hline 338 & 28 & 326 & 40 \\
\hline 280 & 29 & 325 & 27 \\
\hline 300 & 23 & 330 & $351 / 2$ \\
\hline 235 & $201 / 2$ & 320 & 26 \\
\hline 240 & $22^{1 / 2}$ & 315 & 38 \\
\hline 320 & 25 & 315 & 30 \\
\hline 275 & $271 / 2$ & 325 & 36 \\
\hline 340 & 23 & 310 & 23 \\
\hline 235 & 23 & 300 & $351 / 2$ \\
\hline 240 & $281 / 2$ & 265 & 26 \\
\hline 340 & 29 & 275 & 29 \\
\hline 235 & 26 & 270 & 32 \\
\hline 325 & -21 & -270 & $-361 / 2$ \\
\hline$=304$ & $\bar{x}=26.2$ & $\bar{X}=308$ & $\bar{x}=32$ \\
\hline
\end{tabular}

\section{DISCUSSION}

The results of this experiment imply that social facilitation stimulates an increased level of survival stamina resulting in higher levels of physical endurance of animal aggregates as compared to single animals. Such implications are in accordance with findings by Waters, Rethlingshafer, \& Ealdwell (1960), which pose important determinants other than primary biological drives as mechanisms of behavior. However, Gates \& Allee (1933) found no such social facilitatory effects in cockroaches running a maze. Allee (1938) found that social interaction interfered with maze learning of parakeets. However, Waters (1960) found no significant difference between paired and single groups of rats in learning situations. Such findings would seem to imply that increased survival stamina in rats may be dependent upon social facilitation for motivation derivations, but that such social facilitation is void of processes concerning learning. Thus, it is evident that the significantly longer running times accomplished by $\mathrm{P} 1$ rats compared to $S 1$ rats is dependent upon some type of interaction which facilitates stamina.

\section{ALLEE, W. C. Animal aggregations.} Chicago: University of Chicago Press, 1931.

ALLEE; $W$. C. The social life of animals. New York: Norton, 1938.

ALTMAN, J. Organic foundations of animal behavior. New York: Holt, Rinehart \& Winston, 1967. Pp. 431-460.

ALVERDES, F. Social life in the animal world. New York: Harcourt, Brace, 1927.

ANDERSON, E. E. The effects of the presence of a second animal upon emotional behavior in the male albino rat. Journal of Social Psychology, 1939, 10, 265-268.

GATES, M., \& ALLEE, W. C. Conditioned behavior of isolated and grouped cockroaches on a simple maze. Journal of Comparative Psychology, 1933, 15, 331-358.

HARL OW, H. F. Social facilitation of feeding in the albino rat. Psychology, $1932,41,211-221$.

HARLOW, H. F., \& YUDIN, H. C. Social behavior of primates. Journal of Comparative Psychology, 1933, 16, 171-185.

LEPLEY, W. M. Competitive behavior in the albino rat. Journal of Experimental Psychology, 1937, 21, 194-201.

WATERS, R. H. Group and individual maze learning by the albino rat. Psychology Bulletin, 1937, 34, 739 .

WATERS, R. H., RETHLINGSHAFER, D. A., \& EALDWELL, W. E. (Eds.), Principles of comparative psychology. New York: McGraw-Hill, 1960 . Pp. 144-145.

WINSLOW, N. C. A study of experimentally induced competitive behavior in the white rat. Comparative Psychology Monographs, 1940, 15 (Whole No. 6).

YOUNG, P. T. Motivation and emotion. New York: Wiley, 1961. Pp. 224-225. 